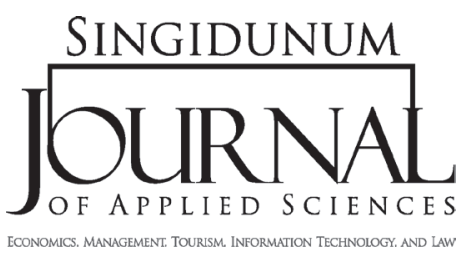

\section{THE PRICING AND VALUATION OF SWAPS}

\author{
Jelena Paunović* \\ Wiener Städtische osiguranje a.d.o. Belgrade \\ 1 Trešnjinog cveta Street, Belgrade, Serbia
}

SINGIDUNUM JOURNAL 2013, 10 (1): 39-45

ISSN 2217-8090

UDK: 005.334:336.764.1

DOI: $10.5937 /$ sjas1301039P

Review paper/Pregledni naučni rad

\begin{abstract}
:
Swaps are financial agreements between two parties to exchange period cash flows and are mostly used as a tool for hedging risk and speculation. They are derivative contracts that derive their value from an underlying asset (the most common underlying assets are the interest rates in the plain vanilla case, but it can be almost anything). These OTC products (over the counter) are traded directly between the two parties or with a financial institution acting as an intermediary.

Some banks in Serbia already offer these derivative instruments, but the markets are still in an emerging phase. The private sector is severely affected by credit and interest rate risk which currently lacks sufficient knowledge and understanding of such products and their importance. This paper aims to present and demystify the structure of these financial derivatives by presenting their valuation methods and by showing how they are used in practice. Ultimately, we shall discuss the credit risk the counterparties are facing in developed financial markets nowadays.
\end{abstract}

( 


\section{INTEREST RATE SWAPS IN PRACTICE}

Interest rate swaps are the most common type of a swap contract. They are also referred to as "plain vanilla interest rate swaps". In this type of swap contract, one company pays to the other cash flows that are equal to the interest at a prearranged fixed rate on a notional principal $\mathrm{N}$ for a certain period of time (Price and Henderson, 2012).

It is important to note that the notional principal $\mathrm{N}$ of an interest rate swap is never exchanged because the contract is based on the same notional denoted in the same currency throughout the entire life of the swap. At the same time, the second company agrees to pay to the first one, in the same currency, cash flows that are equal to the interest at the current floating rate (usually the LIBOR rate) on the same notional principal for the same period of time.

The reason for the existence of such instrument is usually associated with the comparative advantage argument, which means that some companies have a comparative advantage in floating rate markets and others have it in fixed rate markets. Companies usually borrow money from the market where they have a comparative advantage. However, this can sometimes oblige them to borrow floating when they want to borrow fixed and vice versa, which can cause trouble if they have an opposite exposure. This is where the interest-rate swap is useful with the consequence of transforming the floating rate loan into a fixed rate loan. It is an instrument that allows removing interest rate risk over a given period in the future on a regular basis.

\section{The LIBOR rate}

As mentioned earlier, the floating rate is usually the London Interbank Offer Rate (LIBOR) which is the rate at which major banks are willing to offer $\$$ deposits to each other. LIBOR is determined on the inter-banking market and is changing along with the business cycles. The BBA (British Bankers Association) polls panel banks asking them at what rate they would loan money to other panel banks. One reason why the LIBOR is mostly used is because it is the easiest defaultable rate and because a vast majority of interest rate derivatives and many bond issuances are linked to it.

As the LIBOR contains default risk, it is compensated by an interest rate spread above the Treasuries.

\section{A practical example}

Let us imagine an interest rate swap between the World Bank and IBM where company wishes to borrow $\$ 1$ million for 2 years. We will assume for now that there is no intermediary (bank) $\Leftrightarrow$ there are no commissions. The two companies have been offered the following rates:

\begin{tabular}{ccc}
\hline Borrowing rates & Fixed & Floating \\
\hline World Bank & $6,00 \%$ & 6 month LIBOR $+0.4 \%$ \\
\hline IBM & $7.30 \%$ & 6 month LIBOR $+0.9 \%$ \\
\hline
\end{tabular}

Assumptions:

- World Bank would prefer borrowing at a floating rate linked to LIBOR.

- IBM would prefer borrowing at a fixed rate.

We can see that the difference between the two floating rates is $0.5 \%$ and that the difference between the fixed rates is $1.3 \%$. The fixed rate difference is bigger than the difference of the floating rates. IBM pays less interest on the floating markets than on the fixed markets compared to World Bank, which means that IBM has a comparative advantage on the floating market and that World Bank has a comparative advantage on the fixed markets. Both companies can now arrange a swap to guarantee that the World Bank finishes with floating rate payments (as desired) and IBM finishes with fixed rate payments.

The process goes as follows: The World Bank borrows money at $6 \%$ fixed rate (comparative advantage), IBM borrows at the 6 month Libor $+0.9 \%$ rate. They can now agree to enter in a swap contract to ensure that World Bank ends up with a floating rate and IBM ends up with a fixed one.

This swap contract looks as follows:

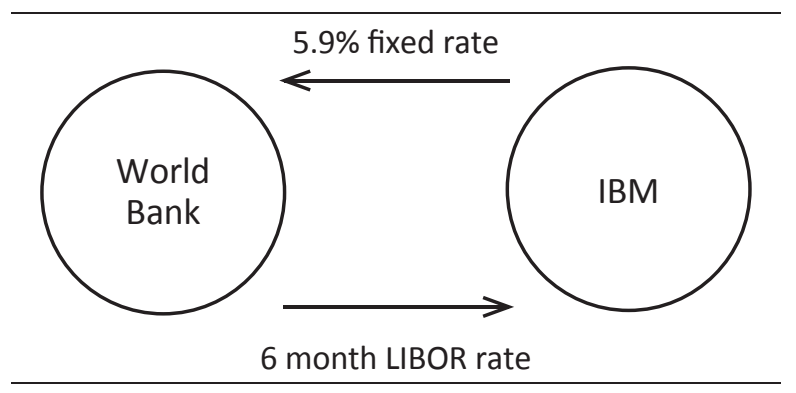

- World Bank pays IBM interest at 6-month LIBOR on $\$ 1$ million notional.

- IBM pays World Bank interest at a fixed rate of 5.9\% per annum on $\$ 1$ million notional. 
Total cash-flows:

- World Bank receives 5.9\% fixed from IBM, pays $6 \%$ fixed to the lenders and pays 6 month LIBOR rate to IBM which is equal to a total net of Libor $+0.1 \%$ per year, which is $0.3 \%$ less than it would have to pay if it borrowed money directly from the floating market at the rate of LIBOR $+0.4 \%$.

- IBM receives 6 month LIBOR from World Bank, pays $5.9 \%$ to World Bank, and pays LIBOR $+0.9 \%$ to the lenders. This sums up to a total net of $6.8 \%$ fixed, which is $0.5 \%$ less per year than if the company went directly to the fixed markets and borrowed at the rate of $7.3 \%$.
The swap improves the positions (McDougall, 1999) for World Bank and IBM by $0.3 \%$ and $0.5 \%$ per year, respectively.

In an interest rate swap, the total gain is always the difference between the interest rates that the two companies have in fixed markets and the difference between the interest rates they have in floating markets. In this case, the total gain is $1.3 \%-0.5 \%=0.8 \%$.

In practice, the two companies usually never get in touch directly in order to make a swap agreement. There is almost always a bank that stands in between as an intermediary, which means the swap could look as follows:

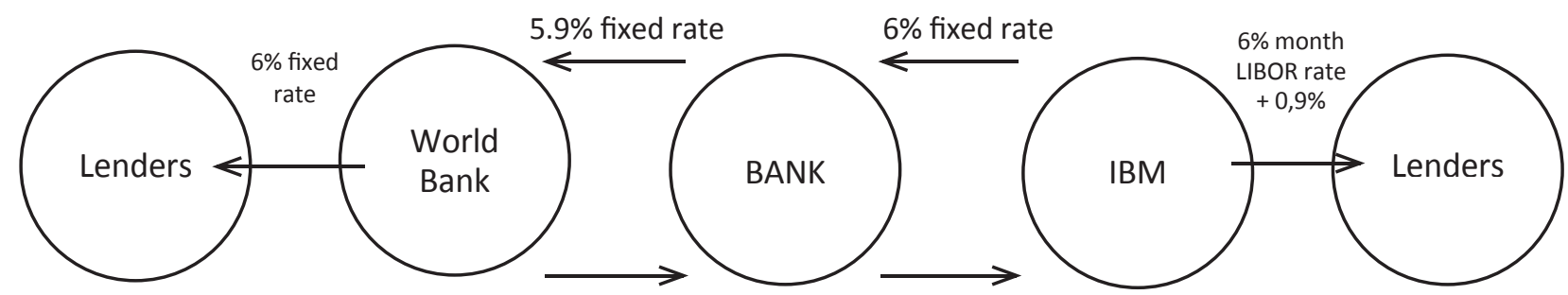

6 month LIBOR rate

6 month LIBOR rate

In this case, the net payment for the World Bank is:

- It receives 5.9\% fixed from the Bank, It pays $6 \%$ to lenders and it pays 6 month LIBOR to BANK which equals to a total net of LIBOR $+0.1 \%$ left to pay per annum which is $0.3 \%$ less than it would have to pay if it borrowed money directly from the floating market at the rate of LIBOR $+0.4 \%$.

The net payment of IBM in this case is:

- It receives 6 month LIBOR rate from the Bank, it pays 6 month LIBOR $+0.9 \%$ to lenders and it pays $6 \%$ fixed to the bank which equals to a total net of $6.9 \%$ fixed left to pay which is $0.4 \%$ less than if the company went directly to the fixed markets and borrowed at the rate of $7.3 \%$.

In that case, the net payment of the bank is:

- It receives $6 \%$ fixed from IBM, it pays $5.9 \%$ fixed to World Bank, it receives 6 month LIBOR from World Bank and it pays 6 month LIBOR to IBM which equals to a total of $0.1 \%$ fixed for the BANK.
The total gain of all parties is the same as in the last example, $0.8 \%$, except that here the bank takes a commission of $0.1 \%$ by taking a higher fixed rate from IBM (6\%) compared to the one it pays to World Bank (5.9\%).

One of the two companies pays for the difference between the fixed and the floating interest every 6 months (cause 6 month LIBOR rate is used in the example, with semi-annual compounding). The first cash flow exchange would take place 6 months after the swap agreement.

The second cash flow exchange would happen 12 months after the swap agreement, based on the forward LIBOR rate in 6 months for 6 months etc. (see Table 1).

If the 6 month LIBOR was 7\%, the first exchange of cash flows would look as follows:

- World Bank would pay to the BANK $0.5 \mathrm{x}$ $(7-5.9) \%{ }^{*} 1000000=5500 \$$.

- The BANK would keep $0.1 \%$ commission which is $500 \$$. 


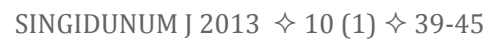

Paunović J. \& The pricing and valuation of swaps

Table 1: Swap cash flows (6\% fixed swap rate, period 5 years, floating LIBOR rate, notional \$10M, semi-annual compounding)

\begin{tabular}{|c|c|c|c|c|}
\hline \multicolumn{5}{|l|}{ Swap rate: $6 \%$} \\
\hline \multicolumn{4}{|c|}{ Contract date: 1/15/2009 } & \multirow{2}{*}{$\begin{array}{c}\text { Notional amount: } \$ 10 \mathrm{~N} \\
\begin{array}{c}\text { Net Payment } \\
\text { (fixed payer) }\end{array}\end{array}$} \\
\hline Date & Fixed Payment & 6-month LIBOR & Floating Payment & \\
\hline $1 / 15 / 2009$ & & $4 \%$ & & \\
\hline $7 / 15 / 2009$ & 300000 & $5 \%$ & 200000 & 100000 \\
\hline $1 / 15 / 2010$ & 300000 & $6 \%$ & 250000 & 50000 \\
\hline $7 / 15 / 2010$ & 300000 & $7 \%$ & 300000 & - \\
\hline $1 / 15 / 2011$ & 300000 & $8 \%$ & 350000 & 50000 \\
\hline $7 / 15 / 2011$ & 300000 & $7 \%$ & 400000 & 100000 \\
\hline $1 / 15 / 2012$ & 300000 & $6 \%$ & 350000 & 50000 \\
\hline $7 / 15 / 2012$ & 300000 & $5 \%$ & 300000 & - \\
\hline $1 / 15 / 2013$ & 300000 & $4 \%$ & 250000 & 50000 \\
\hline $7 / 15 / 2013$ & 300000 & $3 \%$ & 200000 & 100000 \\
\hline $1 / 15 / 2014$ & 300000 & $2 \%$ & 150000 & 150000 \\
\hline
\end{tabular}

Table 2: Pricing a two-year swap with forward rates (\$10M notional, semi-annual compounding).

\begin{tabular}{|c|c|c|c|c|c|c|}
\hline Date & Time & $\begin{array}{l}\text { Fixed pay- } \\
\text { ment }\end{array}$ & $\begin{array}{l}\text { 6-month LIBOR } \\
\text { floating rate }\end{array}$ & $\begin{array}{c}\text { Floating pay- } \\
\text { ment }\end{array}$ & $\begin{array}{c}\text { Expected } \\
\text { Floating Payment }\end{array}$ & $\begin{array}{l}\text { Net Payment (fixed } \\
\text { payer) }\end{array}$ \\
\hline $1 / 15 / 2009$ & 0 & & & & & \\
\hline $7 / 15 / 2009$ & 6 months & $\mathrm{s} / 2 * \$ 10 \mathrm{mil}$ & $r_{0.5}$ & $\left(r_{0.5}\right) / 2 * \$ 10 \mathrm{mil}$ & $\left(r_{0.5}\right) / 2 * \$ 10 M$ & $\left(\mathrm{~s} / 2-\mathrm{r}_{0.5} / 2\right) * \$ 10 \mathrm{mil}$ \\
\hline $1 / 15 / 2010$ & 1 year & $\mathrm{s} / 2 * \$ 10 \mathrm{mil}$ & $r_{0.5}$ in 6 months & - & $\left(\mathrm{f}_{0.5} \mathrm{f}_{0.5}\right) / 2 * \$ 10 \mathrm{M}$ & $\left(\mathrm{s} / 2-0.5 \mathrm{f}_{0.5} / 2\right) * \$ 10 \mathrm{mil}$ \\
\hline $7 / 15 / 2010$ & 1.5 years & $\mathrm{s} / 2 * \$ 10 \mathrm{mil}$ & $r_{0.5}$ in $1 \mathrm{yr}$ & - & $\left(\mathrm{f}_{0.5}\right) / 2 * \$ 10 \mathrm{M}$ & $\left(\mathrm{s} / 2-1 \mathrm{f}_{0.5} / 2\right)^{*} \$ 10 \mathrm{mil}$ \\
\hline $1 / 15 / 2011$ & 2 years & $\mathrm{s} / 2 * \$ 10 \mathrm{mil}$ & $r_{0.5}$ in $1.5 \mathrm{yrs}$ & - & $\left(\mathrm{f}_{1.5} \mathrm{f}_{5}\right) / 2 * \$ 10 \mathrm{M}$ & $\left(\mathrm{s} / 2-1.5 \mathrm{f}_{0.5} / 2\right) * \$ 10 \mathrm{mil}$ \\
\hline
\end{tabular}

\section{VALUATION METHODS}

In order to value an interest rate swap, the first option would be to consider the swap as the sum of a long position and a short position of a bond. We can assume that our swap in the last example is the same as if IBM was lending to the financial institution $\$ 1 \mathrm{M}$ at 6 Month LIBOR and the financial institution lending to IBM $\$ 1 \mathrm{M}$ at a fixed rate of $6 \%$ in return. This is the same as selling a floating rate bond on $\$ 1 \mathrm{M}$ notional and buying a $\$ 1 \mathrm{M}$ notional bond on fixed rate. The value of the swap is then the difference between the values of the two bonds. We denote by $\mathrm{S}$ the value of the swap, $\mathrm{N}$ the notional of the swap, and P1 and P2 the values of the the two bonds $\Leftrightarrow \mathrm{S}=\mathrm{P} 1-\mathrm{P} 2$.

The fundamental concept lying behind bond valuation is the net present value (NPV) of cash flows, which simply means that money received in the future is worth less than that same amount received now. The longer we wait for the payment, the higher the compensation needs to be.
In order to price the bonds, we need to understand forward rates (Howard, 2012).

Suppose we want to borrow or lend $\$ 50$ million in 18 months for a period of 18 months. We can use a forward rate to lock in the rate now:

- The "in 18 month for 18 month" forward rate from now is the rate at which we can borrow or lend in 18 months for a period of 18 months, there is no option. We are obliged to borrow or to lend at the forward rate.We will write that forward rate as: $1.5 \mathrm{f}_{1.5}$, where 1.5 refers to a 18 month period.

Generally, ${ }_{m} f_{n}$ will denote the forward in $m$ years for $n$ years.

\section{Example:}

By no-arbitrage:

$$
\left(1+r_{1} / 2\right)^{2}=\left(1+r_{.5} / 2\right)\left(1+{ }_{.5} f_{.5} / 2\right)
$$

with $r$ the interest rate for year 1, semi-annualy compounded. 
Solving for the forward rate, we see that:

$$
{ }_{.5} f_{.5}=2\left[\frac{\left(1+r_{1} / 2\right)^{2}}{\left(1+r_{.5} / 2\right)}-1\right]
$$

The general formula for the forward rate in $\mathrm{m}$ years for 0.5 years is:

$$
{ }_{m} f_{.5}=2\left[\frac{\left(1+r_{m+.5} / 2\right)^{2 m+1}}{\left(1+r_{m} / 2\right)^{2 m}}-1\right]
$$

What we just did is called "bootstrapping the yield curve" using the spot rates to find the forward rates (see Table 2 ).

In order to be able to price the swap, we have to understand the following:

- in the absence of default risk, a swap is just a sequence of forward contracts.

- it costs zero to enter a swap agreement.

- the swap price refers to the fixed rate that is exchanged with the floating rate which is also called the swap spread.

- In practice, LIBOR zeros which are needed exist only out to 1-year.

Two ways of getting LIBOR zeros are:

1) By going to the LIBOR forward market which is very liquid and by getting forward rates on Bloomberg, and then bootstrapping the forward curve to get LIBOR spot rates. LIBOR forward rates can be found in Bloomberg terminal as "IMM Eurodollar Synthetic forward rates".

2) By bootstrapping the swap curve to get LIBOR zero prices and then get spot rates from these. The question that arises is concerned with the spread we have to pay over the treasury rate to get a fixed rate.

The net present value of fixed cash flows should equal the net present value of floating cash flows which is the same as saying that the net present value of the swap should equal zero.

Putting this into a formula (Marshall and Kapner, 1993):

The expected net NPV of an N-year pay floating/ receive fixed swap is 0 :

$$
0=\sum_{n=1}^{2 N} \frac{1}{\left(1+r_{n / 2} / 2\right)^{n}}\left(\frac{s}{2}-\frac{n / 2-0.5 f_{0.5}}{2)}\right)
$$

This is the same as saying:

$$
\begin{aligned}
N P V_{\text {fixed }} & =\sum_{n=1}^{2 N} \frac{s / 2}{\left(1+r_{n / 2} / 2\right)^{n}}= \\
& =\sum_{n=1}^{2 N} \frac{n / 2-0.5 f_{0.5} / 2}{\left(1+r_{n / 2} / 2\right)^{n}}=N P V_{\text {floating }}
\end{aligned}
$$

Simplifying, it turns out to be a simple general formula for a $\mathrm{N}$ year swap:

$$
s=2 \frac{\left(1-\delta_{N}\right)}{\sum_{n=1}^{2 N} \delta_{n / 2}}
$$

With: $\delta_{n}$ the discount rate at period $n$ (considering semi-annual compounding) which is equal to:

with $r_{n}$ : the interest rate during the period $n$.

$$
\delta_{n}=\frac{1}{\left(1+r_{n / 2} / 2\right)^{2 n}}
$$

and

$$
{ }_{n / 2-0.5} f_{.5}=2\left[\frac{\left(1+r_{n / 2} / 2\right)^{n}}{\left(1+r_{n / 2-0.5} / 2\right)^{n-1}}-1\right]
$$

the forward rate for $\mathrm{n} / 2-0.5$ years for 0.5 years Proof and example for a 1 year swap:

$$
\begin{aligned}
N P V_{\text {fixed }} & =\sum_{n=1}^{2} \frac{1}{\left(1+r_{n / 2} / 2\right)^{n}} \frac{s}{2}= \\
& =\sum_{n=1}^{2} \frac{1}{\left(1+r_{n / 2} / 2\right)^{n}} \frac{n / 2-0.5}{2} f_{0.5}=N P V_{\text {floating }}
\end{aligned}
$$

Where:

$\mathrm{NPV}($ floating $)=$

$\sum_{n=1}^{2} \frac{1}{\left(1+r_{n / 2} / 2\right)^{n}} \frac{n / 2-0.5}{2} f_{0.5}=\sum_{n=1}^{2} \frac{1}{\left(1+r_{n / 2} / 2\right)^{n}}\left[\frac{\left(1+r_{n / 2} / 2\right)^{n}}{\left(1+r_{n / 2-0.5} / 2\right)^{n-1}}-1\right]$

$=\frac{1}{\left(1+r_{0.5} / 2\right)^{1}}\left[\frac{\left(1+r_{0.5} / 2\right)^{1}}{\left(1+r_{0} / 2\right)^{0}}-1\right]+\frac{1}{\left(1+r_{1} / 2\right)^{2}}\left[\frac{\left(1+r_{1} / 2\right)^{2}}{\left(1+r_{0.5} / 2\right)^{1}}-1\right]$

$=\left[\frac{1}{\left(1+r_{0} / 2\right)^{0}}-\frac{1}{\left(1+r_{0.5} / 2\right)^{1}}\right]+\left[\frac{1}{\left(1+r_{0.5} / 2\right)^{1}}-\frac{1}{\left(1+r_{1} / 2\right)^{2}}\right]$

$=\frac{1}{\left(1+r_{0} / 2\right)^{0}}-\frac{1}{\left(1+r_{0.5} / 2\right)^{1}}+\frac{1}{\left(1+r_{0.5} / 2\right)^{1}}-\frac{1}{\left(1+r_{1} / 2\right)^{2}}$

$=1-\frac{1}{\left(1+r_{1} / 2\right)^{2}}=1-\delta$ 
$\mathrm{NPV}($ fixed $)=$

$\sum_{n=1}^{2} \frac{1}{\left(1+r_{n / 2} / 2\right)^{n}} \frac{s}{2}=\frac{s}{2}\left(\frac{1}{\left(1+r_{0.5} / 2\right)^{1}}-\frac{1}{\left(1+r_{1} / 2\right)^{2}}\right)=\frac{s}{2}\left(\delta_{0.5}+\delta_{1}\right)$

NPV(floating $)=\operatorname{NPV}($ fixed $) \Leftrightarrow$

$\frac{s}{2} \sum_{n=1}^{2} \delta_{n / 2}=1-\delta_{1} \quad \Leftrightarrow \quad s=2 \frac{\left(1-\delta_{1}\right)}{\sum_{n=1}^{2} \delta_{n / 2}}$

\section{Example:}

If we have a 6 month rate $\mathrm{r}_{0.5}=4 \%$ and 1 year rate $r_{1}=5 \%$ then the swap rate $\mathrm{s}$ is:

$$
s=2 \frac{\left(1-\delta_{1}^{L}\right)}{\sum_{n=1}^{2} \delta_{n / 2}{ }^{L}}=4,988 \%
$$

\section{Risks associated with interest rate swaps}

It is important to know that the discount rates we use in valuing the swap should reflect the riskiness of the cash flows. Since we are using the LIBOR (denoted with $\mathrm{L}$ ) as a representation of the floating rates, the risk is then associated with loans in the interbank market.On the other hand, the use of interest rate swaps exposes the trader to two types of primary risk: interest rate risk and credit risk (counter-party risk)

\section{Interest rate risk:}

As the interest rate movements do not usually go with investors hope, swaps involve an interest rate risk. The counterparty that is receiving fixed profits if the rates fall and loses if they rise. On the other hand, the fixed payer profits if rates rise and loses if they fall (see Chart 1 below). When the swap is put "at the money", this means the total value of fixed interest-rate during the life of the swap is the same as the anticipated value of the floating rate cash flows, which is why the price to enter a swap is zero as mentioned earlier. At the inception of the swap, the NPV of the anticipated profits and losses should add up to zero.

\section{Credit risk:}

Financial institutions which are highly accredited usually market-make the swaps by offering either fixed and floating rate cash flows to their customers. It is important to notice that when they enter a swap, they have two independent contracts (Marshall and Kapner, 1993). This means they have to honor the agreement with the other company if one defaults (credit risk). Generally, the company entering the swap would not even know that the bank has hedged the position with another company. Because of this, most of the large banks are prepared to store the swaps, which means entering into a swap while hedging the interest rate risk until a counterparty wanting to take opposite position is found (mostly done with rate-locking). If a swap transaction is massive, the market maker may organize to sell it to a number of counterparties so that the risk of the swap becomes additionally spread and thus, the market makers decrease their risk exposure. The credit risk is very small as the swap market makers are generally highly accredited financial institutions but it is still above U.S. treasury bonds.

\section{Chart 1: Swap interest rate risk}

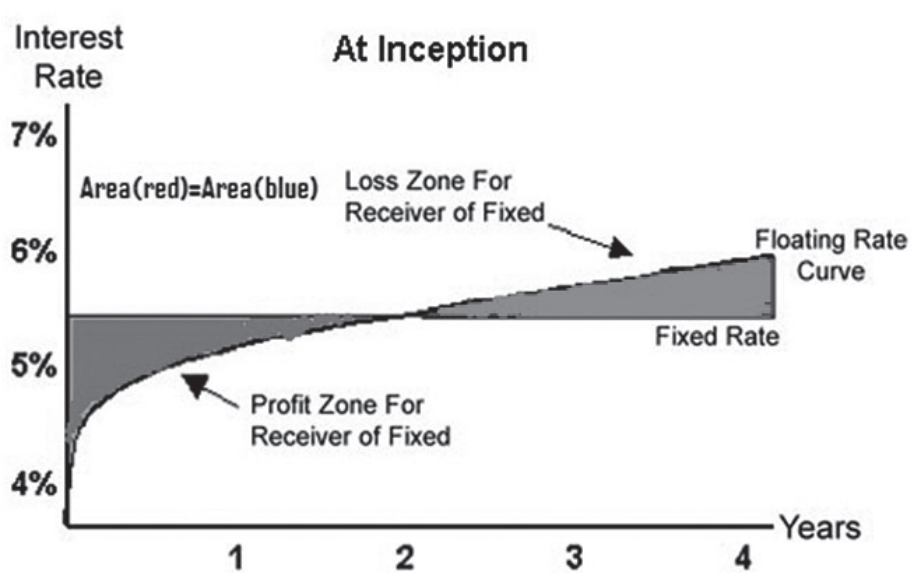




\section{CONCLUSION}

The interest rate swap markets have been present for decades in the developped world as a way for companies to deal with their debt and they have grown into one of the most liquid OTC markets world-wide. They enable indirect access to fixed or floating capital markets and allow the counterparties to manage their asset/liability structure. Interest rate swaps are commonly used by companies in order to receive a marginally lower interest rate than they would have been able to get without them. However, swap markets are still at an inception phase in Serbia. We presented in this paper swap valuation methods that rely on the net present value of cash flows (NPC) along with practical examples. We also introduced two types of risk that companies and market makers face, the interest-rate risk and credit risk, in order to emphasize the importance of swaps for the private sector, which currently requires more understanding of these derivative products.

\section{REFERENCES}

Buetow, G.W., Fabozzi, F. J. (2001) Valuation of interest rate swaps and swaptions. New Hope, Pa.: Frank J. Fabozzi.

Howard, C. (2012) Interest Rate Swaps and Other Derivatives. New York: Columbia Business School.

Marshall, J. F., Kapner, K.R. (1993) Understanding Swaps. New York; Chichester: Wiley.

McDougall, A. (1999) Mastering Swaps Markets: a stepby-step guide to the products, applications and risks. London: Financial Times.

Price, J., Henderson, S. (2012) Currency and interest rate Swaps. London: Butterworths.

Flavell, R. (2010) Swaps and other derivatives. San Francisco: John Wiley and Sons.

\section{ODREĐIVANJE CENE I VREDNOVANJE SVOPOVA}

\section{Rezime:}

Svopovi su finansijski ugovori između dve strane za razmenu tokova novca različitog porekla i koriste se uglavnom kao sredstvo za upravljanje rizikom (hedžing) i spekulacije.To su derivatni instrumenti čija se vrednost izvodi iz osnovne aktive (najčešći tip je generički svop ili 'vanila kamatni svop', ali to može biti skoro bilo šta). Ovim OTC (vanberzanskim) proizvodima se trguje nesposredno između dve strane ili sa finansijskom institucijom koja nastupa kao posrednik.

Pojedine banke u Srbiji već nude ove derivatne instrumente, ali je njihovo korišćenje na tržištu još uvek u začetku. Kreditni rizik i rizik kamatne stope u velikoj meri utiču na privatni sektor koji trenutno ne poseduje dovoljno znanja o takvim proizvodima i njihovom značaju. Cilj ovog rada je da pokuša da prikaže i razjasni strukturu ovih finansijskih derivata tako što predstavlja metode za njihovo vrednovanje i pokazuje kako se one primenjuju u praksi. Na samom kraju ovog rada ćemo se pozabaviti pitanjem kreditnog rizika sa kojim se ugovorne strane danas suočavaju na razvijenim finansijskim tržištima.

\section{Ključne reči:}

svopovi,

finansijski derivati,

OTC (vanberzansko) tržište,

hedžing,

rizik,

spekulacije,

finansijska tržišta.

Received: January 23rd, 2013

Correction: February 25th, 2013

Accepted: March 8th, 2013 